this would mean transferring funds away from specialist centres into primary care and prevention.

1 Public Health Laboratory Service. AIDS/HIV quarnerly surveillance tables. No 16. London: PHLS, 1992

2 National Audit Office. HIV and AIDS related health services. London: HMSO, 1991.

3 NHS Management Executive. Allocation for AIDS work. London: Department of Health, 1992. (EL(92)18.)

4 NHS Management Executive. HIVIAIDS allocation. Leeds: Department of Health, 1993. (EL(93) 19.)

5 Layzell S, McCarthy M. Community-based health care for people with HIVI AIDS in Nonh East Thames Regional Health Authority. London: Department of Epidemiology and Public Health, University College London, 1992.
6 Layzell S, McCarthy M. Community-based health services for people with HIV/AIDS: a review from a health service perspective. AIDS Care 1992;4:205-18.

7 NHS Mangement Executive. Hospice funding. London: Department of Health, 1992. (EL(92)16.)

8 Camden and Islington HIV prevention: developing a strategy for the nineties. London: Camden \& Islington Community Health Services Trust, 1993.

9 United Kingdom Health Departments. AIDS-HIV infected health care workers. practical guidance on notifying patients. London: Department of Health,

10 Aboulker J-P, Swart AM. Preliminary analysis of the Concorde trial. Lancet 1993;341:889-90.

(Accepted 25 May 1993)

\title{
"War on drugs" continues in United States under new leadership
}

\author{
D M Gorman
}

Criticism of the "war on drugs" pursued under Republican administrations has grown in the United States. With the election of Bill Clinton many experts expected a shift from law enforcement policies to an approach favouring treatment and prevention. The budget announced in April, however, revealed no such shift in allocation of resources. Although the war on drugs has apparently failed to reduce the supply of cheap heroin and cocaine to the United States, the prevention strategy favoured by its opponents-school based prevention programmes-has not yet been shown to be effective in dealing with the concentration of drug misuse among the socially disadvantaged. In looking for new strategies Clinton must satisfy both liberals and conservatives in Congress, and community policing might therefore prove to be a politically expedient option.

After months of anticipation of fundamental changes in the United States government's approach to the country's drug problem, the budget announced recently by President Bill Clinton's administration showed virtually no shift in emphasis from that of its Republican predecessor.' Most of the $\$ 13.04$ billion to be spent in the next year remains allocated to law enforcement and interdiction ( $\$ 8.30$ billion), and only $\$ 4.74$ billion will go to treatment and prevention. This is essentially the same two thirds to one third division that existed under the Bush administration and that came under increased

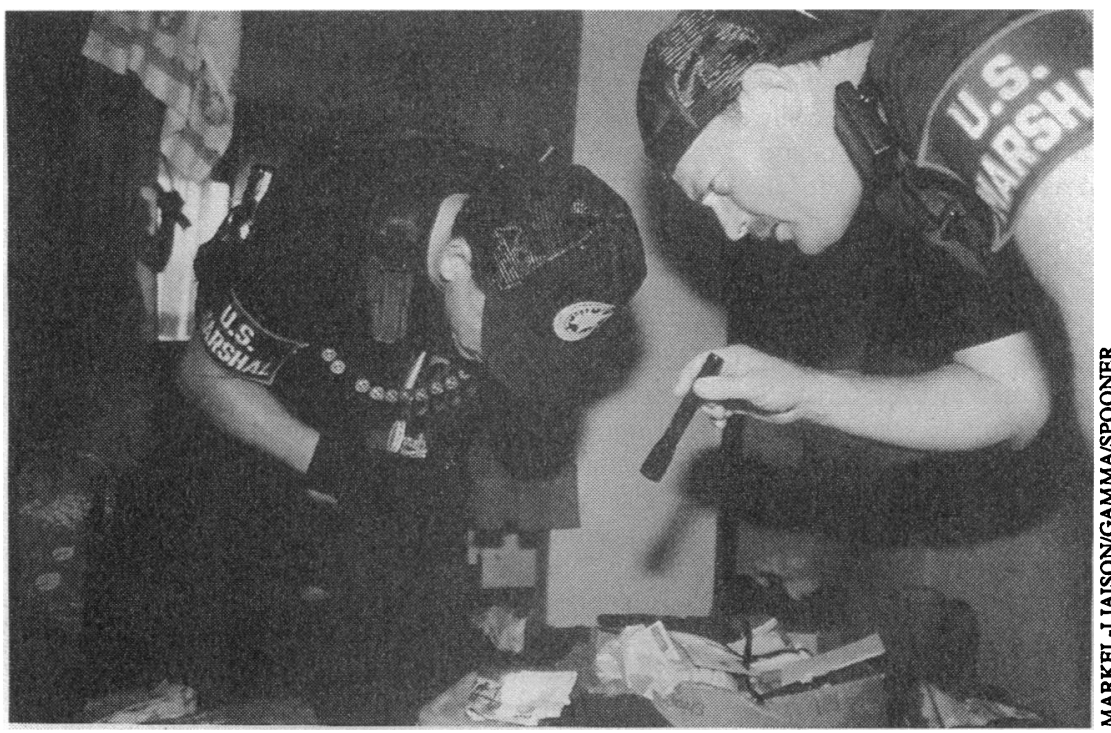

Despite the war on drugs, heroin and cocaine are still readily available criticism due to its reliance on apparently ineffective strategies designed to reduce supply. ${ }^{2}$

\section{Shift to reducing demand was anticipated}

Expectations of change had been raised in part because Clinton appeared to be listening to people criticial of the emphasis on law enforcement and interdiction. Notable among these was Mathea Falco, who was an advisor to Clinton during his presidential campaign and who recently wrote a book on the drug problem that received the endorsement of Vice President Al Gore. ${ }^{34}$ In the book's first chapter on the "supply-side seduction," Falco documents the failure of recent policies either to prevent the flow of cheap drugs into the United States or to reduce the ease with which they can be purchased in most large cities.

The case against the "war on drugs" policies that the Reagan and Bush administrations pursued with such enthusiasm is that they have failed to achieve their most basic objective, to reduce the supply of heroin and cocaine to the United States. Despite the billions of dollars spent over the past 12 years and increased numbers of drug seizures and drug related arrests, the purity of heroin and cocaine sold on the streets has increased while prices have fallen and the disease and social disorder resulting from the trade in illicit drugs has escalated, especially in inner cities. For example, in New York City the retail price of a gram of cocaine was $\$ 70-\$ 100$ in 1986 while in 1991 it was $\$ 50-\$ 90.5$

Other recently published books have also drawn attention to the limitations and inadequacies of prevailing policies, ${ }^{67}$ and such criticism is increasingly finding its way into the popular press. ${ }^{28}$ Where the critics part company, however, is in the alternatives they propose-these include decriminalisation of illicit drugs $^{6}$ and substantial investment aimed at rebuilding America's inner cities. ${ }^{7}$ In this respect Falco is more pragmatic by asking for a shift to reducing demand, arguing that it is justified not only because attempts to reduce supply have failed but also because there are now effective treatment and prevention programmes. She does not suggest a huge increase in public spending or a dramatic turn about in social norms concerning drug use but rather a redistribution of existing resources and a shift in emphasis in how the United States views its drug problem.

In terms of prevention Falco follows the prevailing trend by lavishly praising the "social influences" approach, which teaches adolescents to identify pressures to use drugs (said to come mainly from the adverstising media and peers) and the skills necessary to resist such influences. Instruction tends to follow a set curriculum and is typically delivered in schools to 
children aged 12-13. This approach has come to dominate the field of primary prevention in the United States and has recently been adapted for use in Great Britain. ${ }^{9}$ Proponents of the social influences approach argue that it represents a major improvement over earlier knowledge based and affect based programmes and has uses beyond the prevention of cigarette smoking for which it was first developed. Others point out that, while this method may have a statistically significant effect on the misuse of alcohol and marijuana compared with non-intervention, the actual levels of drug use involved tend to be small and, therefore, its practical significance remains in question..$^{10}$ This raises the possibility that what is generally considered our most effective primary prevention strategy may reduce misuse of drugs only among those at minimal risk to begin with. ${ }^{11}$

\section{Drug misuse concentrated in inner cities}

The last point about the social influences approach is particularly relevant to the intractable nature of addiction to crack cocaine and heroin in the inner cities. ${ }^{12-14}$ Indeed, it has recently been suggested that drug misuse, like other social ills, is becoming another dimension of the increasing divide between rich and poor in the United States. ${ }^{15}$ Thus, although the most recent data available indicate that the problem of illicit drug misuse is by no means banished from the middle classes,${ }^{16}$ the worst drug misuse is concentrated in urban ghettoes. ${ }^{17}$

Falco acknowledges in her book that there are few programmes that target adolescents and children living in such high risk environments, and those that she does discuss are basically extensions of the social influences model to include family and community components as well as the school. A fundamental problem with such an approach is that the socioeconomic factors that underlay the concentration of drug misuse in inner cities-economic decline and stagnation, high unemployment, poor housing conditions, and social isolation and disorganisation-also result in many of those who live under such conditions having no family or community that cares for them. ${ }^{17}$ To expect an expanded version of the social influences programme to have a significant impact on drug misuse in inner cities is misguided since it ignores the underlying causal factors operating in these settings. This does not mean that those concerned with preventing misuse of drugs can only sit back and await some dramatic restructuring of cities but rather that intervention programmes must be properly informed by an understanding of the aetiology of the problem in the targeted population..$^{10}$

Published evaluations of prevention programmes conducted in inner cities are rare. Indeed, much of what we know about drug misuse among socially disadvantaged people comes from media accounts and studies using techniques such as ethnography that fall outside the mainstream of social science research in the United States. ${ }^{1819}$ Reasons for the lack of research in such settings include the obvious threats to personal safety $^{20}$ and the extreme difficulty of doing "good science" under such cirumstances. For example, staff implementing prevention programmes in impoverished neighbourhoods often find it difficult to deny much needed services to individuals on the random basis required in an experimental design. ${ }^{21}$ In contrast, denying some middle class students a particular type of prevention curriculum in a school and community where other programmes are, in all likelihood, routinely in operation and where serious drug misuse is probably relatively rare will present much less of a moral dilemma to those who administer and implement programmes. For this reason, they are likely to be

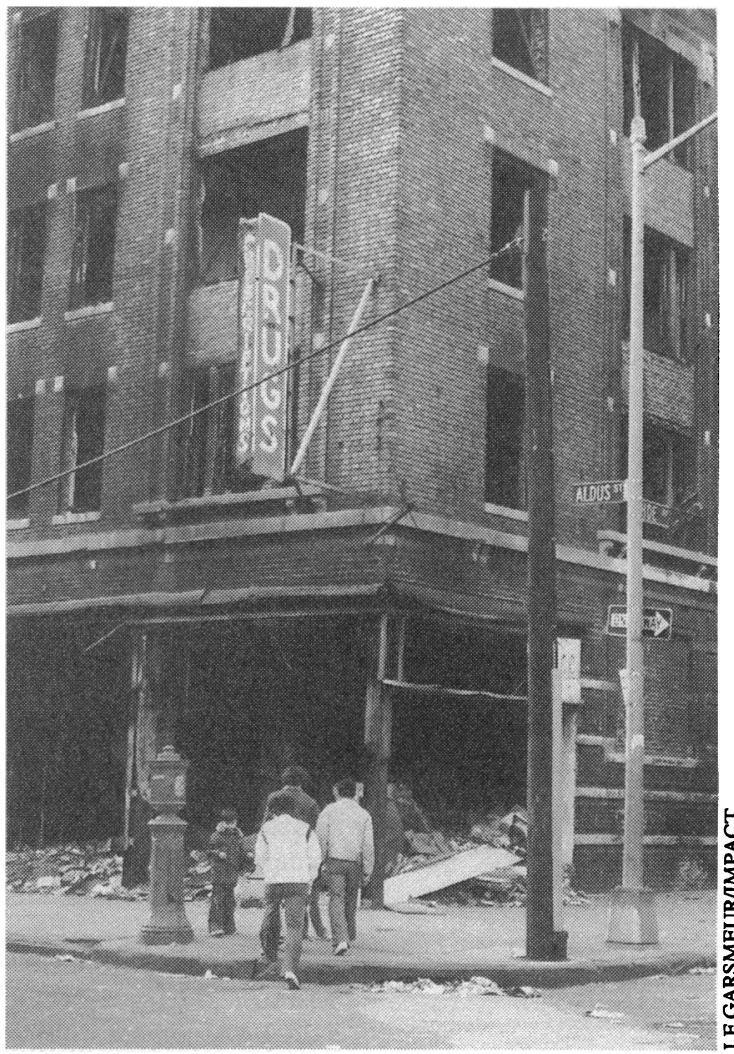

American inner cities are where the worst drug misuse is concentrated

more accommodating to researchers than are workers in inner cities facing seemingly overwhelming problems with minimal resources at their disposal.

As a consequence, evalations of school based interventions (most of which are not conducted in the most blighted neighbourhoods) have become increasingly sophisticated in terms of research design and thus set exacting standards by which funding bodies judge proposed evaluations of other prevention strategies. While funding agencies are right to insist on methodological rigour in programme evaluation they have yet to provide much guidance on how this might best be achieved when working with the most socially disadvantaged sectors of society. Thus, for the average (middle class) researcher-seeking external funding from research institutes, wishing to publish in prestigious journals, and valuing personal safetythere are clear disincentives to evaluate programmes targeted at those at greatest risk of becoming drug misusers.

\section{Constraints on changes in policy}

One possible reason why the Clinton administration has chosen not to alter course on drug policy is that there are at present simply too many competing demands, both national and international, to allow the necessary time to be spent developing a fundamentally new approach. Certainly, since being elected, Clinton has shown little interest in drug policy and recently cut the staff of the Office of National Drug Control Policy from 147 to $25 .{ }^{1}$ Some viewed this as a scaling down of the drug war and as a portent of changes to come, ${ }^{8}$ but what appears to have happened is that altering policy has been assigned a relatively low priority. ${ }^{1}$

Those still hopeful of change after the budget announcement saw two possible opportunities for a future shift in policy. One was the proposed health care reforms being developed by a taskforce headed by Hillary Clinton: these could include increased spending on drug treatment, ${ }^{14}$ although their implications for prevention and education are more uncertain. The other was the appointment of a director of the Office of 
National Drug Control Policy, a cabinet position which remained vacant until the end of April. Clinton's choice of former New York city police commissioner Lee $\mathrm{P}$ Brown met a mixed response. Some were concerned that the main emphasis of federal policy would remain law enforcement given the new director's background while others observed that Brown had an open mind about alternative approaches and might be able to sell a shift in policy to Congress without appearing to be "soft on drugs." 22

The need to be tough on addicts and dealers might, in fact, represent the biggest obstacle to changing direction in drug policy since drugs and crime are inextricably linked in the American consciousness. ${ }^{38}$ Indeed, in the book recently published by Bill Clinton and $\mathrm{Al}$ Gore drugs and crime share a four page chapter together, and putting "more police on the street" and "more criminals behind bars" are given as much emphasis as treatment and education. ${ }^{23} \mathrm{At}$ a time when moderate and conservative Democrats are voicing concern that Clinton is moving too far to the left ${ }^{24}$ the president and his new director of drug policy may find it politically expedient to conduct business as usual.

With regard to the inner cities, however, one option they might pursue is that of community based programmes designed to create a partnership between residents and the police, ${ }^{25}$ a strategy that Brown has experience of from his days as police commissioner in New York City. This approach includes traditional components of law enforcement designed to "stabilise" communities - such as establishing a visible police presence, increasing the number of arrests, and developing an efficient system of surveillance and intelligence. In addition, it attempts to "activate" community members by improving channels of communication between individuals and groups, making state and local agencies more responsive to residents' needs, and facilitating the development of neighbourhood organisations. This approach to prevention is obviously tough on drug dealers and their customers-its primary objective being to rid a neighbourhood of its illicit drug market-and is therefore unlikely to be opposed by conservatives. At the same time, its emphasis on community activism and empowerment is attractive to liberals. It might therefore represent the perfect compromise strategy for the Clinton administration, although the ability of such programmes to engage the residents of those neighbourhoods most ravaged by drug misuse has yet to be demonstrated. ${ }^{26}$

\section{Two wars on drugs}

Two recently published books on the Vietnam war have highlighted the extent to which this was mainly fought by the most disadvantaged social classes in American society and how this influenced the tactics employed in the conflict. ${ }^{27}$ In the war on drugs the same sector of American youth has in effect become the enemy, and the strategies employed in dealing with it are essentially those of social control and containment. In contrast, a battle for hearts and minds is fought in the more affluent sectors of society with tactics that, even if the political will to use them existed, would probably be ineffectual in countering the greater risk experienced by children growing up in the urban ghettoes of the United States.

1 Treaster JB. Clinton is chided on drug problem: critics see old inadequacies in \$13.04 billion package. New York Times 1993 April 12;sect A:1, sect B:10.

2 Treaster JB. Echoes of Prohibition: 20 years of war on drugs, and no victory yet. New York Times 1992 June 14;sect E:7.

3 Falco M. The making of a drug free America: programs that work. New York: Times Books, 1992.

4 Massing M. The rehabbing of America. New York Times Book Review 1993 Jan $24 ; 10$.

5 Bureau of Justice Statistics. Drugs, crime, and the justice system: a national report. Washington, DC: US Government Print Office, 1992.

6 Staley S. Drug policy and the decline of American cities. London: Transaction, 1992.

7 Currie E. Reckoning: drugs, cities, and the American future. New York: Hill and Wang, 1993.

8 Reuter P. Truce in needle park: time to end the drug war. Washington Post 1993 Feb 28;sect C:1-2.

9 Bagnall G. Educating young drinkers. London: Routledge, 1991.

10 Gorman DM. Using theory and basic research to target primary prevention programs: recent developments and future prospects. Alcohol Alcohol 1992;27:583-94

11 We need a guerrilla war on drugs [editorial]. Int 9 Addict 1993;28:ii-v.

12 McNagy SE, Parker RM. High prevalence of recent cocaine use and the unreliability of patient self-report in an inner-city walk-in clinic. $尹 A M A$ 1992;267:1106-8.

13 Tabor MBW. The world of a drug bazaar, where hope has burned out. New York Times 1992 Oct 1;1.

14 Treaster JB. Emergency hospital visits rise among drug abusers. New York Times 1993 April 24;8.

15 Kandel D, Davies $M$. Decline in the use of illicit drugs by high school students in New York State: a comparison with national data. Am $\mathcal{f}$ Public Health in New York 1 :81:1064-7.

16 Treaster JB. Drug use by younger teenagers appears to rise, counter to trend. New York Times 1993 April 14;1.

17 Dunlap E, Johnson BD. The setting for the crack era: macro forces, micro Dunlap E, Johnson BD. The setting for the crack era: macro fo
consequences (1960-1992). f Psychoactive Drugs 1992;24:307-27.

18 Tierney J. Fernando, 16, finds a sanctuary in crime. New York Times 1993 April 13;1.

19 Dunlap E. The impact of drugs on family life and kin networks in the innercity African-American single parent household. In: Harrell AV, Peterson GE, eds. Drugs, crime, and social isolation: barriers to urban opportunity. Washington, DC: Urban Institute Press, 1992:181-207.

20 Williams T, Dunlap E, Johnson BD, Hamid A. Personal safety in dangerous places. Fournal of Contemporary Ethnography 1992;21:343-74.

21 Lorion RP, Ross JG. Programs for change: a realistic look at the nation's potential for preventing substance involvement among high-risk youth foumal of Community Psychology 1992;20:3-9. (OSAP special issue.)

22 Treaster JB. Ex-police commissioner to be Clinton drug 'czar'. New York Times 1993 April 28;15.

23 Clinton B, Gore A. Putting people first: how we can all change America. New York: Times Books, 1992.

24 Kelly $M$.'New Democrats' say Clinton has veered left and left them. New York Times 1993 May 23;20.

25 Greene JR, McLaughlin E. Facilitating communities through police work drug problem solving and neighborhood involvement in Philadelphia. In Davis RC, Lurigio AJ, Rosenbaum DP, eds. Drugs and the community: involving community residents in combatting the sale of illegal drugs. Springfield Illinois: Thomas, 1993:141-61.

26 Skogan WG, Annan S. Drug enforcement in public housing. In: Davis RC, Lurigio AJ, Rosenbaum DP, eds. Drugs and the community: involving community residents in combatting the sale of illegal drugs. Springfield, Illinois: community residents in

27 Weigley RF. Putting the poor in uniform. New York Times Book Review 1993 April $11 ; 12$.

(Accepted 3 fune 1993) 